P-ISSN: 2774-4574; E-ISSN: 2774-4574 TRILOGI, 2(1), Januari-April 2021 (53-60) @2021 Lembaga Penerbitan, Penelitian, dan Pengabdian kepada Masyarakat (LP3M) Universitas Nurul Jadid Paiton Probolinggo DOI: https://doi.org/

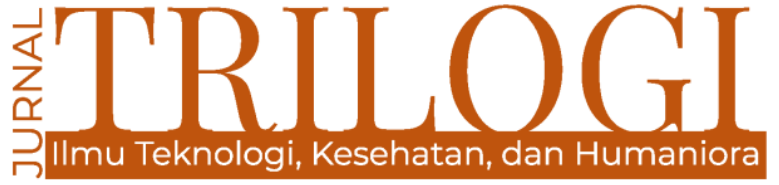

\title{
PEMBELAJARAN ANAK USIA DINI DALAM KAJIAN NEUROSAINS
}

\author{
Salamah Eka Susanti \\ Program Studi Pendidikan Agama Islam, Fakultas Agama Islam, \\ Universitas Zainul Hasan, Probolinggo \\ salamahekasusanti99@gmail.com
}

\begin{abstract}
Brain is a center of human intelligence that controls the nervous system in learning process. Early childhood education through a neuroscience approach is possible to be implemented through various methods, including the way teachers provide education firstly need to understand the performance of the human brain. In addition, it also pays attention to the natural work of the learner's brain in the learning process. The purpose of this study is to describe the importance of neuroscience approach for early childhood in the learning process. This research method is an intertextual approach by emphasizing the method of meaning of creativity and the type of research used is qualitative research in the form of literature (library research). The results of this study are as follows: 1) a early childhood teacher needs to apply a neuroscience approach in learning to assist teachers in achieving competence for their students, especially for early childhood; 2 ) the strategy of a nearly childhood teacher needs to apply a neuroscience approach by understanding the stages of development of the intelligence center as a teacher does not only provide experience, but more importantly is facilitated and stimulated to optimize the development of intelligence capacity for his students.
\end{abstract}

Keywords: Learning; Early childhood; Neuroscience

\begin{abstract}
Abstrak
Otak merupakan pusat kecerdasan manusia yang mengendalikan sistem syaraf dalam menangkap suatu pembelajaran. Pendidikan anak usia dini melalui pendekatan neurosains dapat dilaksanakan melalui macam metode, diantaranya dengan cara guru memberikan pendidikan dahulu dan harus memahami kinerja otak manusia. Selain itu juga memperhatikan kerja alamiah otak peserta didik dalam proses pembelajaran. Tujuan penelitian ini yaitu untuk mendeskripsikan pentingnya memahami pendekatan neurosains bagi anak usia dini dalam proses pembelajaran. Metode penelitian ini yaitu menggunakan pendekatan intertektualitas dengan menekankan metode meaning of creatifity dan jenis penelitian yang digunakan yaitu jenis penelitian kualitatif dalam bentuk kepustakaan (library research). Hasil dari penelitian ini yaitu sebagai berikut : 1) seorang guru PAUD perlu menerapkan pendekatan neurosains dalam pembelajaran untuk membantu guru dalam mencapai kompetensi bagi anak didiknya khususnya bagi anak usia dini; 2) strategi seoang guru PAUD menerapkan pendekatan neurosains dengan memahami tahapan-tahapan perkembangan pusat kecerdasan seperti halnya seorang guru tidak hanya memberikan pengalaman saja, akan tetapi yang lebih utama difasilitasi dan distimulan untuk mengoptimalkan perkembangan kapasitas kecerdasan bagi anak didiknya.
\end{abstract}

Katakunci: Pembelajaran; Anak Usia Dini; Neurosains 


\section{Pendahuluan}

Hakekat pendidikan adalah optimalisasi potensi manusia atau peserta didik. Seluruh potensi manusia semua bertumpu pada otaknya. Pengertian pendidikan dalam hal ini dibatasi pada pengembangan potensi manusia, khususnya potensi yang bertumpu pada otaknya. Pendidikan secara umum mengikuti jejak dalam neurosains, pendidikan tersebut dapat dilihat dalam upaya optimalisasi fungsi otak untuk mencerdaskan peserta didik. sedangkan neurosains mempunyai jejak di dalam Islam. Jejak neurosains dalam alQur'an dapat ditemui pada istilah-istilah yang digunakan al- Qur'an untuk menyebut aktifitas otak, seperti: tafakkur (berfikir), tadabur (merenung) tabashshur (memahami) (Noeng Muhadjir, 2011)

Selama ini pendidikan Islam belum menaruh perhatian yang serius terhadap neurosains. Neurosains adalah ilmu yang mempelajari anatomi otak. Pendidikan adalah optimalisasi seluruh potensi peserta didik. Seluruh potensi peserta didik bertumpu pada otaknya. Sehingga, Neurosains mempunyai jejak di dalam Islam dan pendidikan mempunyai basis yang kuat di dalam A-Qur'an. Oleh karena itu, pendekatan Neurosains sangat penting dalam studi-studi kependidikan Islam. Padahal, di dunia barat istilah neurosain telah menjadi alat penting bagi pengembangan kurikulum pendidikan, khususnya program ekselarasi. Ekpansi neorosain ke dunia pendidikan di Barat juga melahirkan banyak teori belajar berbasis otak, misalnya : quantum learniosaing, contectual teaching and learning, dan brain based learning (Taufik Pasiak, 2006: 46).

Neurosains merupakan sebuah rujukan yang dipakai oleh para pakar pendidikan Islam. Neurosains menemukan bahwa seluruh potensi anak didik bertumpu pada otaknya. Selanjutnya dijelaskan, bahwa anak didik yang baru lahir mempunyai 100-200 miliar neuron (sel saraf) dan kecerdasannya berkembang hingga $50 \%$ sampai anak usia 6 bulan (Adi W. Gunawan, 2003). Pada usia dua tahun perkembangan otaknya mencapai $75 \%$, dan pada usia 10 tahun perkembangan kecerdasannya telah mencapai 90\%. Diatas usia sepuluh tahun perkembangan otak semakin lambat sehingga untuk mencapai perkembangan kecerdasan $100 \%$ harus menunggu hingga anak berusia 18 tahun.

Neurosains merupakan sistem pendidikan yang mempelajari tentang sistem kerja syaraf.
Pendidikan pada umumnya kurang memperhatikan sistem ini. Pengabaian terhadap sistem ini menyebabkan suasana pembelajaran menjadi monoton. Di dalam dunia pendidikan, para peneliti terjadi perdebatan tentang neurosains, yaitu memisahkan dan menyatukan tiga elemen (otak-pikiran, jiwa-badan, akal-hati) belum menemukan titik temu. Kebanyakan sistem melarang peserta didik untuk memakai otakpikiran dalam pembelajaran yang selama ini para didik dituntut untuk menjaga kemuliaan hati dan akhlak mulia (Aminul Wathon, 2015 : 284).

Sejak dipublikasikannya teori tentang neurosains, khususnya fakta mengenai perkembangan otak anak. Terlebih lagi temuan dibidang neurosains mengantarkan para psikolog untuk sampai pada kesimpulan bahwa usia dini merupakan usia emas (golden ages). Hal ini telah dikemukan oleh seorang psikolog terkemuka, yaitu Howard Gardner, ia menyatakan bahwa anak pada usia lima tahun pertama selalu diwarnai dengan keberhasilan dalam belajar mengenai segala hal. Gardner memberikan tiga penjelasan mengenai keberhasilan anak tersebut (Howard Gardner, t.t : 199).

Di Indonesia, penelitian tentang neurosains relatif masih tergolong rendah, yaitu hanya 0,19 $\%$. Diantaranya hasil penelitian yang relevan dengan pembelajaran, seperti : (1) neurosains dengan pendekatan pendidikan Islam, pembentukan karakter, berpikir kreatif, kerjasama dan konseling, (2) seni dapat memengaruhi kecerdasan dan emosional peserta didik, (3) efektivitas pembelajaran dengan memaksimalkan dan menstimulasi fungsi kedua belahan otak (Rahmi Rivalina, 2020: 88).

Istilah "otak" untuk menyebut kecerdasan anak, yang digunakan Neurosains dipahami secara sempit oleh kalangan praktisi pendidikan, khususnya praktisi PAUD. Menurut UU nomor 20 Tahun 2003 tentang Sistem Pendidikan Nasional , Bab 1, Pasal 1 Butir 14 pasal 28 tentang Pendidikan Anak Usia Dini yang menyatakan bahwa : (1) pendidikan anak Usia Dini diselenggarakan sebelum jenjang pendidikan dasar, (2) pendidikan Anak usia dini dapat diselenggarakan melalui jalur pendidikan formal, non formal, dan/atau informal, (3) Pendidikan anak usia dini jalur pendidikan formal: TK, RA, atau bentuk lain yang sederajat, (4) Pendidikan anak usia dini jalur pendidikan non formal: KB, TPA, atau bentuk lain yang sederajat, (5) Pendidikan anak usia dini jalur pendidikan informal: pendidikan keluarga atau pendidikan 
yang diselenggarakan oleh lingkungan, (6) ketentuan mengenai pendidikan anak usia dini sebagaimana dimaksud dalam ayat (1), (2), (3), dan (4) diatur lebih lanjut dengan peraturan pemerintah.

Implikasinya, pengelolaan PAUD terutama TPA (0-2 tahun) dan KB (usia 2-4) lebih condong untuk berintegrasi dengan Posyandu dari pada Taman Pendidikan Al-Qur'an (TPQ). Padahal Posyandu hanya mengontrol kesehatan atau jasmani anak, terutama otak anak. Sedangkan TPQ mempunyai basis edukasi secara memadai, bahkan kurikulum yang ada telah diselaraskan dengan fitrah, potensi maupun karakter anak sehingga tumbuh kembang anak tidak sebatas fisik sebagaimana dalam posyandu, melainkan sosial- emosional, fisik-motorik, moral-spiritual.

Neurosains membagi anatomi otak menjadi tiga belahan, yaitu : otak kiri, otak kanan, dan otak tengah. Hasil kerja otak kiri disebut IQ, hasil kerja otak kanan disebut EQ, dan hasil kerja otak tengah disebut SQ. Selanjutnya Neurosains menjelaskan bahwa bermain dapat mengaktivasi otak kiri (IQ), musik dapat mengaktivasi otak kanan (EQ), sedangkan cerita atau sosio drama khususnya kisah-kisah agung spiritual dapat mengaktivasi otak tengah (SQ).

Namun dalam realitanya ketiga aktivasi tersebut tidak dilaksanakan pada pendidikan PAUD, bermain yang seharusnya membuat anak senang sehingga otak kirinya hidup akan tetapi justru dimuati pelajaran yang membuat otak kiri anak tidak aktif, bernyai yang seharusnya menekankan nada justru menekankan muatan edukasi dalam lirik lagu. Dan cerita yang seharusnya merangsang imajinasi transendental melalui sentuhan emosi positif justru diisi dengan dongeng mistik yang tidak ada muatan spiritualitasnya.

\section{Metode}

Jenis penelitian ini yaitu jenis penelitian kualitatif dalam bentuk kepustakaan (library research). Pendekatan penelitian ini menggunakan pendekatan intertektualitas dengan menekankan metode meaning of creatifity. Analisis yang dipakai adalah hermeneutik phenomenologik. Sumber data dalam penelitian ini dari hasil-hasil penelitian maupun dengan menggunakan buku yang relevan yang sesuai dengan tema penelitian. Selain itu dalam penelitian ini juga memakai pemikiran para filosof muslim tentang insan kamil yang berkaitan dengan jasmani, ruhani, dan akal. Selanjutnya, dalam penelitian ini juga dikaji pemikiran para neurolog terkait dengan cara kerja otak, baik otak kiri (rasional), otak kanan (kreatif), dan otak kanan (intuitif) (Noeng Muhadjir , 2011 : 118119).

\section{Hasil dan Pembahasan}

\subsection{Teori tentang Neurosains}

Neurosains secara etimologi adalah ilmu neural (neural science) yang mempelajari sistem syaraf, terutama mempelajari neuron atau sel syaraf dengan pendekatan multidisipliner. Sedangkan secara terminologi, Neurosains merupakan bidang ilmu yang mengkhususkan pada studi saintifik terhadap sistem syaraf. Dengan dasar ini, neurosains disebut juga sebagai ilmu yang mempelajari otak dan seluruh fungsifungsi syaraf belakang (Aminul Wathon, 2015 : 285).

Neurosains merupakan satu bidang kajian mengenai sistem syaraf yang ada di dalam otak manusia. Neurosains juga mengkaji tentang kesadaran dan kepekaaan otak dari segi biologi, persepsi, ingatan, dan kaitannya dengan pembelajaran. Sistem syaraf dan otak merupakan bagian fisikal bagi proses pembelajaran manusia. Neurosains merupakan penelitian tentang otak dan pikiran. Studi tentang otak menjadi landasan dalam pemahaman tentang bagaimana kita merasa dan berinteraksi dengan dunia luar dan khususnya yang dialami manusia dan bagaimana manusia mempengaruhi yang lain (Schneider , 2011).

Otak adalah organ tubuh manusia yang posisinya ditempatkan Tuhan secara terhormat dibagian atas tubuh manusia dan terlindungi dengan kokoh dibagian dalam tengkorak kepala. Posisi otak ini merupakan simbol yang menunjukkan bahwa manusia lebih mulia daripada makhluk ciptaan Tuhan yang lainnya. Muhammad

Neurosains, secara sederhana adalah ilmu yang khusus mempelajari neuron (sel saraf). Berdasarkan, hasil penelitian di bidang neurologi, bahwa pertumbuhan sel jaringan otak pada anak usia 0-4 tahun mencapai 50\%, hingga anak usia 8 tahun mencapai $80 \%$ dan kematangan pada usia 10-25tahun. Artinya, apabila pada urutan usia tersebut otak tidak mendapatkan rangsangan yang optimal maka perkembangannya tidak akan maksimal. Semakin dini penanganan dan bentuk rangsangan yang diberikan terhadap anak maka hasilnya akan semakin baik. Sebaliknya, semakin lambat, maka semakin buruk hasilnya. Dalam 
berbagai materi lain dijelaskan, bahwa kurikulum pembelajaran neurosains juga berkembang disiplin ilmu sistem saraf yang berhubungan antara amnusia dengan Tuhan yang sangat berkaitan dengan jasmaniah. Materi spiritualitas dalam pembelajaran neurosains terdiri dari dua variabel yaitu spiritualitas dan intelektualitas. Konsep teoritis spiritualitas terdiri tiga komponen yaitu Spiritual Health Item, Brain System Assessment, dan Neurofeedback. Oleh sebab itu, spiritual dalam Islam lebih bersifat individualistik fokus pada pemikiran dan argumentasi yang dianggap benar (Trisna Dewi, Nur Fitri Wulandari, Ovi Soviya, t.t : 266).

Sel-sel saraf ini menyusun sistem syaraf, baik susunan syaraf pusat yaitu otak dan syaraf tulang belakang maupun syaraf tepi yaitu 31 pasang saraf spinal dan 12 pasang saraf kepala. Sel saraf (neuron) adalah sinapsis yaitu titik pertemuan 2 sel saraf yang memindahkan informasi neurotransmitter. Pada tingkat biologi molekuler, unit terkecilnya adalah gen-gen (kajian genetik). Umumnya para neurosaintis memfokuskan pada sel saraf yang ada di otak. Neurosains juga dijelaskan dalam al-Qur'an , seperti tafakkur (berfikir), tadabbur (merenung), tabassur dan memahami. Pemaknaan kalimat tersebut dikontruksikan secara kreatif (meaning of creatifity), sebagaimana ayat Al-Qur'an yang menggunakan istilah neurosains. Oleh karena itu, teori neurosains dalam pendidikan Islam untuk diintegrasikan (Citra Trisna Dewi, Nur Fitri Wulandari, Ovi Soviya, t.t : 269).

Teori belajar neurosains adalah teori belajar yang menekankan pada kinerja otak yaitu tentang bagaimana keseluruhan proses berfikir, proses berfikir juga mencakup hal yang luas dari proses berpikir tersebut menghasilkan pengetahuan, sikap, prilaku atau tindakan. Dalam teori neurosais ini, kualitas seorang anak dapat dinilai dari proses tumbuh kembang. Proses tumbuh kembang merupakan hasil interaksi faktor genetik dan faktor lingkungan. Faktor genetik atau keturunan adalah faktor yang berhubungan dengan gen yang berasal dari ayah dan ibu, sedangkan faktor lingkungan meliputi lingkungan biologis, fisik, psikologi dan sosial.

Menurut teori pembelajaran neurosains, otak luar yang berfungsi yang berfungsi untuk berpikir kritis dan kreatif pada otak anak usia dini belum berkembang maksimal sehingga belum bisa merespon stimulus yang bersifat abstrak dan rasional. Karakteristik otak pada tahap ini baru bisa menerima stimulus yang bersifat kongkrit dan empirik, seperti bermain. Berdasarkan keterangan neurosains tersebut PAUD yang memberikan stimulus abstrak tidak sesuai dengan perkembangan otak anak sehingga beresiko merusak otak anak (Suyadi, 2018 : 277).

Neurosains mempelajari manusia, diantaranya mempelajari perilaku (karakter) melalui pemahaman terhadap cara kerja sel-sel syaraf, khususnya interaksi otak-pikiran, jiwabadan, dan hati-akal. Tumpuan utama neurosain adalah neuroatiatonzi dan fletiologi yaitu ilmu yang membahas arsitektur dan fungsi khusus persyarafan dengan pendekatan yang lebih makro. Dalam hal ini, termasuk struktur sel syaraf secara mikroskopis dan bagaimana sel syaraf tersebut berhubungan satu dengan yang lainuntuk membentuk sebuah sirkuit (wiring diagram) dan masih banyak cakupan dalam kajian neurosains (Aminul Wathon, 2016 : 290).

Menurut Drew, ada empat jenis keterampilan berpikir, yaitu : 1) convergent analytical thinking, proses untuk menghasilkan jawaban tunggal terbaik. Memberdayakan ingatan, sumberdaya di sekitar, atau logika; 2) divergent thinking (kebalikan dari konvergen), proses ekplorasi berbagai solusi, ide-ide baru yang tidak terbatas, mencari tahu prosedur baru untuk memecahkan masalah. Kecenderungan proses berpikir dengan maslah abstrak yang memiliki banyak kemungkinan jawaban, solusi, dan hasil. (3) critical thinking melibatkan analisis melalui pengetahuan dan intelektual. Terdiri dari tiga proses, yaitu deduction (menyimpulkan berdasarkan fakta), induction (menyimpulkan berdasarkan generalisasi), dan abduction (menyimpulkan berdasarkan kemungkinan atau logis. (4) creative thinking, berpikir dengan cara yang tidak konvensional untuk menghasilkan ideide baru tentang topik yang sudah mapan. Mencoba mengatasi masalah dari sudut pandang yang belum pernah dilakukan sebelumnya (Rahmi Rivalina, 2020 : 99).

Menurut Paulin Pasiak, otak hanya bisa didefinisikan jika dikaitkan dengan pikiran. Tanpa pengertian ini, otak tidak memberikan makna apaapa selain sebuah benda yang tidak berbeda dengan benda-benda biologis lainya. Demikian pula dengan jiwa-badan dan akal-hati. Semuanya tidak dapat dipisahkan satu sama lain dengan otak. Semua entitas itu (pikiran, jiwa, dan hati) bersumber pada otak manusia. Disinilah neuroanatomi dan neurofisiologi menjadi bermakna sebagaimana dimaksud sejak pertama kalinya ilmu ditemukan (Aminul Wathon, 2016 : 287). 


\subsection{Penerapan Neurosains dalam Pendidikan Anak Usia Dini}

Perkembangan neurosains sebagai sebuah pengetahuan mengenai sistem syaraf atau tentang otak manusia saat ini mengalami kemajuan yang signifikan. Para pakar terus melakukan penelitian mengenai hubungannya dengan kehidupan manusia termasuk dunia pendidikan dimana keunikan dari perkembangan kemampuan otak sangat terkait dengan output capaian dari sebuah proses pendidikan. Namun, terkadang manusia berpikir seperti teknologiteknologi tersebut dimana otak digunakan sebagai tempat penyimpanan semata. Padahal kenyataannya, otak belajar dengan campuran berbagai emosi, ingatan, niat, dan sebagainya yang membentuk kehidupan mentalnya. Untuk itulah, dalam proses pembelajaran, sebenarnya otaklah yang memasukkan informasi ke dalam wadah yang sebelumnya telah berisi informasiinformasi yang berkaitan sehingga membutuhkan restrukturisasi, penyusunan, dan penilaian kembali (Desfa Yusmaliana, 2019 : 274).

Disamping guru, orang tua juga perlu memahami teori neurosains. Orangtua merupakan guru pertama anak. Secara teori pembentukan dan perkembangan sel dasar otak banyak dipengaruhi oleh orang tua dan lingkungan. Sel darah yang membangun otak dan sitem syaraf (neuron) pada embrio terjadi sejak berumur tiga minggu, diturunkan dari rekombinasi genetik kedua orang tua, gizi seimbang dan stimulasi positif dari ibu seperti suara ibu, degup jantung, tarikan nafas, sentuhan dan belaian diperut yang lembut, dan pengaruh negatif seperti halnya obat keras, kafein, narkoba, alkohol, nikotin, radiasi, teratogen dan emosi yang tidak stabil ( Rahmi Rivalina, 2020: 88).

Pada era teknologi yang semakin canggih sekarang ini, menuntut adanya inovasi dalam pembelajaran, kemajuan teknologi harus dimanfaatkan sebaik mungkin oleh pendidikan agama Islam. Pendayagunaan teknologi dalam proses pembelajaran menjadi keharusan sehingga proses pembelajaran menjadi keharusan sehingga proses pembelajaran tidak stagnan. Inovasi pembelajaran pendidikan agama Islam harus segela direlasikan, terutama dalam metode pembelajaran. Internet sebagai media pembelajaran dapat menjadi alternatif metode pembelajaran, hal ini dapat diwujudkan dalam bentul e-learning, atau aplikasi-aplikasi yang memudahkan penyampaian meteri pembelajaran, sehingga proses pembelajaran semakin menarik dan tidak membosankan.
Potensi kecerdasan berkembang dengan pesat apabila orangtua, guru, dan lingkungan memahami neurosains dan memberikan stimulan secara optimal. Stimulan tersebut dapat mempengaruhi dapat mempengaruhi kualitas anak dan memantau proses perkembangan kemampuan anak. Berikut akan saya jabarkan mengenai peran orangtua dan guru berdasarkan tahapan kecerdasan, yaitu sebagai berikut :

1. Penglihatan, mendekatkan benda ke dekat mata bayi, terus menggerakkan benda tersebut ke kiri, ke kanan, ke atas, dan ke bawah bahkan melingkar.

2. Berbicara, memperkenalkan beragam bunyi yang indah, menarik, dan spesifik seperti lantunan ayat suci, musik, lagu, suara dan bunyi (binatang dan lingkungan sekitar). Perhatikan respon bayi melalui mata, telinga, dan gerakan tubuhnya. Anak dapat meniru, dang mengucapkan seperti yang didengar.

3. Emosi, untuk mengontrol emosi anak ciptakan suasana yang nyaman dan menyenangkan. Mengarahkan memotivasi emosi anak ke hal yang positif, berupa bujukan, ajakan, dan penjelasan logika sederhana.

4. Berpikir, melatih berpikir logika sederhana, berpikir kritis (sebab akibat), menghitung dengan angka-angka rendah dan melatih daya ingat dengan pengulangan.

5. Keterikatan dan keterampilan sosial, memfasilitasi dan memotivasi anak belajar keterampilan soft dan hard skill seperti menari, berenang, melukis, memainkan alat musik, melakukan permainan yang melatih daya pikir. Melibatkan anak dalam kegiatan rumah yang tidak membahayakan.

6. Motorik, kecerdasan motorik sudah terjadi sejak bayi dalam kandungan. Untuk memfasilitasi motorik anak agar lebih terampil dan cekatan dengan membawa mereka ke arena yang lebih luas agar bebas bergerak sambil mengingatkan bahaya yang mungkin mereka temui.

7. Keterampilan sosial sebaya, berikan contoh yang membangun karakter, bekerjasama, bertoleransi bersikap, disiplin dan saling menghargai.

8. Berbahasa, melatih bicara mulai dari kata sampai kalimat yang sederhana. Kalimat sebab akibat dengan logika sederhana. Memotivasi dan menumbuh kembangkan minat membaca, bercerita dan menulis. Perkenalkan anak dengan beragam objek dan minta mereka bercerita. Orang tua khususnya bapak yang rajin berbicara kepada anaknya akan mempercepat peningkatan 
kosakata anaknya secara signifikan (Rahmi Rivalina, 2020: 90).

Pada usia keemasan, diharapkan orangtua dan guru PAUD bijak memberikan beragam stimulan. Pada masa ini anak tidak hanya diberikan pengalaman tapi yang lebih utama difasilitasi dan distimulan untuk mengoptimalkan perkembangan kapasitas kecerdasannya (Uce, 2017). Pengalaman awal anak memiliki dampak besar pada perkembangan otak dan pembelajaran. Semakin banyak anak mendapatkan pengalaman semakin banyak tumbuh neuron-neuron (sel syaraf, sel dasar yang membangun otak dan sistem syaraf).

Pendekatan pendidikan Islam dalam pembentukan karakter anak usia dini sangat penting sehingga potensi yang dimiliki peserta didik dalam berbagai kegiatan belajar dapat tercapai dalam kondisi lingkungan yang enak, nyaman, dan senang. Selain itu, kurukulum neurosains juga penanaman nilai yang membentuk budi pekerti, nilai seni, nilai budaya, kecerdasan, keterampilan, dan agama. Dengan pemikiran tersebut, neurosains bersumber pada wahyu sebagai kawasan transendetal yang rasional, empiris, dan intuitif. (Citra Trisna Dewi, Nur Fitri Wulandari, Ovi Sovia, 2018 : 267).

Menurut Suyadi, bahwa neurosains belum mendapat perhatian dalam pendidikan Islam. Penyebab lain bahwa pendidikan Islam memisahkan antara IQ, EQ, SQ, dan MaQ. Padahal, di Amerika neurosains telah menjadi alat penting bagi perumusan kurikulum pendidikan, khusunya program akselerasi atau percepatan. Alasanya, objek utama pendidikan adalah pengembangan seluruh potensi peserta didik bertumpu pada otaknya. Satu-satunya ilmu yang mempelajari otak adalah neurosains, sehingga pendidikan harus melibatkan neurosains di dalamnya (Suyadi, 118).

Para ahli pendidikan berpendapat, bahwa usia anak-anak adalah usia keemasan (the golden ages). Maria Montessori menyebutnya sebagai sensitive period dan Friedrich Froebel mengibaratkan anak-anak dengan blooming flower. Para psikolog menemukan bahwa masa kanak-kanak adalah masa yang penuh daya imajinasi. Anak mempunyai daya imajiner yang lebih beragam dari pada orang dewasa. Terlebih lagi ketika anak-anak bermain peran, yakni memerankan tokoh dari sebuah cerita, maka imajinasinya akan menghidupkan daya fantasinya sehingga ia seolah-olah benar-benar menjadi sosok yang diperankan tersebut (Suyadi, 2010 : 27). Disamping itu, anak juga mempunyai rasa ingin tahu yang tinggi. Dorongan rasa ingin tahu membuat anak-anak tidak pernah kenal lelah walaupun jatuh-bangun berulang-kali ketika belajar merangkak dan berjalan, misalnya.

Berangkat dari pandangan dikotomis dalam pendidikan Islam tersebut, neurosains, khususnya otak kanan dan otak kiri atau IQ dan EQ juga dipahami secara dikitomis pula. Akibatnya, pendidikan Islam tidak menaruh perhatian pada neurosains karena tidak mampu mencetak agamawan. Ironisnya, pandangan dikotomis tentang neurosains, khususnya otak kanan, kiri, dan tengah dipahami secara sepihak, khususnya pengembangan otak kiri semata. Akibatnya, peserta didik hanya dikembangkan otak kiri (IQ) maupun kognisinya. Sehingga, peserta didik hanya bisa memahami masalah namun tidak mampu mengatasi masalah; bisa memahami berbagai teori, tetapi tidak mampu menyintesiskan teori; bahkan seringkali bisa menentukan sikap dan pilihan tertapi tidak berani mengambil keputusan.

Hal serupa juga dialami bagi pendidikan islam, apabila hanya mengembangkan belahan otak kanan saja. Sehingga peserta didik menjadi sangat kreatif, imajinatif, dan artistik, tetapi tidak logis, tidak kritis, juga tidak analitis. Akibatnya, peserta didik berani mengambil keputusan tetapi konyol karena tanpa memalui pemikiran kritis, logis dan sistematis; bisa menciptakan produk baru akan tertapi kurang bermutu, bisa berkhayal tetapi tidak rasional. Sebagai implikasi lebih lanjut, bentuk-bentuk kecerdasan yang kemudian hari berkembang pesat, dari IQ, EQ, hingga SQ$M a Q$, terkesan parsial bahkan bertentangan satu sama lain. IQ dianggap lebih rendah dari EQ terlebih lagi SQ-MaQ. Disisi lain, Eqtidak mampu melepaskan dari jasa besar yang dikembangkan IQ (Suyadi, 2012 : 119).

Secara sederhana, neurosains diartikan sebagai ilmu yang secara khusus mempelajari dan mengkaji sistem syaraf atau sistem neuron (sel syaraf) pada manusia. Neurosains berkaitan erat dengan ketrampilan metakognitif yang merupakan keterampilan berpikir tingkat tinggi. Dalam prosesnya keterampilan metakognitif ini melalui tahapan regulasi emosi, kesadaran, memonitor proses kognitisi. Terjadinya proses berpikir tingkat tinggi merupakan tugas dari bagian depan otak yang disebut dengan lobus prefrontal/prefrontal cortex. Belahan otak bagian depan dikenal sebagai pusat kontrol eksekutf atau pusat terjadinya berpikir tingkat tinggi. Juga tempat upaya pemecahan masalah, regulasi demensi emosi, penentu watak dan karakter serta kepribadian seseorang

Ruqoyyah Fitri, 2017: 49).

Pembelajaran berbasis kemampuan otak (neurosains) adalah pembelajaran yang 
dihubungkan dengan otak yang dirancang alamiah untuk belajar. Setelah mempelajari teori ini, diharapkan untuk dapat diterapkan dalam proses pembelajaran. Setelah dijelaskan hasil penelitian dari berbagai tempat dalam forum konferensi tingkat tinggi yang dicetuskan oleh Jhon Hopkins University, maka dapat diambil beberapa kesimpulan seperti para ahli menyarankan para orang tua agar siswa mengikuti kegiatan seni musik, karena seni musik dapat merangsang otak, meningkatkan kemampuan bersosialisasi, meningkatkan rasa empati, dan seterusnya. Semakin banyak anak mendapatkan stimulus melalui seni, maka semakin cerdaslah anak tersebut. Seni juga mempunyai beberapa manfaat, seperti : seni dapat membuat kepekaan anak terhadap alam. Seni juga dapat memberikan kenangan dan dapat membantu mempeajari berbagai ketrampilan sesuai dengan kemampuannya (Citra Trisna Dewi, Nur Fitri Wulandari, 2018 : 278).

Mengutip dari video e-learning ITB, dalam proses pembelajaran, guru kurang memberikan contoh permasalahan, melakukan apersepsi atau pengulangan bagi siswa yang belum mengerti, dan sering menyamaratakan kemampuan siswa (elearning ITB, 2017). Memiliki guru ideal dan profesional sebuah harapan dan prioritas. Untuk itu perlu memperhatikan banyak hal, diantaranya bagaimana rekrut dan program yang diberikan untuk calon guru oleh lembaga Pendidikan dan Tenaga Kependidikan. Seorang guru mampu menumbuh kembangkan motivasi intrinsik dan ekstrinsik untuk mempelajari pengetahuan lain dalam menunjang proses pembelajaran ( Rahmi Rivalina, 2020 : 86)

Menurut Moh. Hasan Machfoed, mengatakan neurosains adalah ilmu yang mencoba mengungkapkan misteri otak. Otak menentukan kualitas hidup dan kehidupan seseorang (Ikrar dan Pharm, 2015). Untuk itu seorang guru perlu mempelajari lebih spesifik tentang pusat kecerdasan otak / neurosains. Para ahli pendidikan menyambut positif penetrasi neurosains untuk pendidikan. Guru mempunyai hak istimewa dan kesempatan meningkatkan kualitas dan kuantitas jalur penghubung neuron agar otak mereka dapat dioptimalkan untuk kesuksesan masa depan anak didiknya. Memahami perkembangan anak usia dini, sekolah dasar, anak autis, kebutuhan khusus, dan sulit belajar. Anak harus memiliki waktu tidur yang cukup dan perlu ada jeda waktu pembelajaran. Melakukan gaya belajar pengulangan dan beragam pendekatan (Lynch, 2017).

Seluruh potensi manusia bertumpu pada otaknya (kiri-rasional, kanan-kreatif, dan tengah- intuitif-imajinatif). Selanjutnya, pendidikan mempunyai jejak dalam neurosains, sedangkan neurosains mempunyai jejak di dalam Islam. Oleh karena itu, neurosains dan pendidikan Islam dapat dipadukan. Pendekatan psikologi memungkinkan para ahli memahami pendidikan Islam dalam mekanisme optimalisasi fungsi otak. Dengan demikian, antara insan kamil (jasmani, ruhani, dan akal), neurosains (otak kiri-rasional, otak kanan- kreatif dan otak tengah intuitif), sistem kecerdasan (IQ, EQ, dan SQ) dan pikologi (kognitif, efektif, dan psikomotorik).

Implikasi Neurosains Islamic Education terhadap peserta didik pada jenjang SD atau MI adalah anak yang berusia 6-12 tahun. Dalam neurosains, otak anak pada usia ini telah melewati masa peka atau masa keemasan. Data-data neurosain menunjukan bahwa anak yang baru lahir mempunyai 100-200 miliyar neuron (sel saraf) dan kecerdasanya berkembang hinggs 50\% sampai usia 6 bulan (Adi W. Gunawan, 2003 : 57). Pada usia 2 tahun perkembangan otaknya mencapai $75 \%$, pada usia 5 tahun mencapai $90 \%$, dan pada usia 10 tahun perkembangan kecerdasannya telah mencapai 99\% . tetapi, di atas usia ini, perkembangan kecerdasan anak semakin lambat sehingga untuk mencapai perkembangan kecerdasan $100 \%$ perlu menunggu hingga usia 18 tahun. $\mathrm{Di}$ atas kecerdasan tersebut otak sudah tidak berkembang lagi, kecuali sebatas koneksi antar sel (neuron) (Adi W Gunawan, 2003: 57).

Data- data dari neurosais, menjadi pertimbangan utama untuk dimulainya membangun karakter bangsa sejak dini. Menurut Ahmar Tafsir, bahwa anak yang tidak dikembangkan aspek moral keagamaannya kelak dimasa dewasa akan menjadi orang yang relatif sulit untuk dididik moralitas dan keagamaan (Ahmad Tafsir, 2003: 107). Jika ditarik kesimpulan, bahwa anak usia SD merupakan masa transisi. Berikut ini dikemukakan beberapa indikasi masa transisi bagi anak usia SD. 1) dari usia dini ke usia dewasa atau remaja, 2) dari masa keemasan manuju masa keafkiran, 3) dari masa percepatan otak menuju masa perlambatan, 4) dari masa permainan ketika TK menuju pembelajaran ketika di SD.

\section{Conclusion}

Neurosains merupakan suatu ilmu yang mempelajari tentang mengenai sistem syaraf otak manusia. Neurosains juga mengkaji tentang kesadaran dan kepekaaan otak dari segi biologi, persepsi, ingatan, dan kaitannya dengan 
pembelajaran. Sistem syaraf dan otak merupakan bagian fisikal bagi proses pembelajaran manusia. Neurosains merupakan penelitian tentang otak dan pikiran. Upaya mengoptimalkan pencapaian hasil belajar bagi anak usia dini yaitu melalui beberapa tahapan, antara lain sebagai berikut : 1) diharapkan orangtua dan guru PAUD bijak memberikan beragam stimulan. Pada masa ini anak tidak hanya diberikan pengalaman tapi yang lebih utama difasilitasi dan distimulan untuk mengoptimalkan perkembangan kapasitas kecerdasannya; 2) Potensi kecerdasan berkembang dengan pesat apabila orangtua, guru, dan lingkungan memahami neurosains dan memberikan stimulan secara optimal. Stimulan tersebut dapat mempengaruhi dapat mempengaruhi kualitas anak dan memantau proses perkembangan kemampuan anak; 3) para ahli menyarankan para orang tua agar siswa mengikuti kegiatan seni musik, karena seni musik dapat merangsang otak, meningkatkan kemampuan bersosialisasi, meningkatkan rasa empati, dan seterusnya. Semakin banyak anak mendapatkan stimulus melalui seni, maka semakin cerdaslah anak tersebut.

\section{References}

Tafsir, A. (1992). Ilmu pendidikan dalam perspektif Islam. Remaja Rosdakarya.

Gunawan Adi, W. (2003). Genius Learning Strategy. Petunjuk praktis untuk menerapkan accelerated learning. Jakarta: Gramedia

Tafsir, A. (2006). Filsafat Pendidikan Islami Integrasi Jasmani, Rohani dan Kalbu. Memanusiakan Manusia). Bandung: Remaja Rosdakarya.

Suyadi, S. (2012). Integrasi Pendidikan Islam dan Neurosains dan Implikasinya Bagi Pendidikan Dasar (PGMI). Al-Bidayah: Jurnal Pendidikan Dasar Islam, 4(1), 2345.

Dewi, C. T., Fitri, N. W., \& Soviya, O. (2018). Neurosains dalam Pembelajaran Agama Islam. Ta'allum: Jurnal Pendidikan Islam, $6(2), 259-280$.
Awhinarto, A., \& Suyadi, S. (2020). Otak Karakter Dalam Pendidikan Islam: Analisis Kritis Pendidikan Karakter Islam Berbasis Neurosains. Jurnal Pendidikan Karakter, 10(1), 1-25.

Pasiak, T. (2006). Manajemen Kecerdasan: memberdayakan IQ, EQ, dan Sq untuk kesuksesan hidup. Bandung: Mizan.

Muhadjir, N. (2011). Metodologi penelitian edisi VI pengembangan 2011. Yogyakarta: Rake Sarasin.

Wathon, A. (2016). Neurosains dalam pendidikan. Jurnal Lentera: Kajian Keagamaan, Keilmuan dan Teknologi, 14(1), 284-294.

Suyadi, S. (2019). PENDIDIKAN ISLAM ANAK USIA DINI DALAM PERSPEKTIF NEUROSAINS: ROBOTIK, AKADEMIK, DAN SAINTIFIK. Edukasia: Jurnal Penelitian Pendidikan Islam, 13(2), 273-304.

Fitri, R. (2017). Metakognitif pada proses belajar anak dalam kajian neurosains. JP (Jurnal Pendidikan): Teori Dan Praktik, 2(1), 5664.

Rivalina, R. (2020). Pendekatan Neurosains Meningkatkan Keterampilan Berpikir Tingkat Tinggi Guru Pendidikan Dasar. Kwangsan, 8(1), 332456.

Suyadi, S. (2010). Konsep Edutaiment Dalam Pembelajaran di Tingkat SD/MI (Antisipasi Keterkejutan Mental Anak Pada Masa Transisi Dari TK/RA ke SD/MI). AlBidayah: Jurnal Pendidikan Dasar Islam, 2(1).

Yusmaliana, D., \& Suyadi, S. (2019). Pengembangan Imajinasi Kreatif Berbasis Neurosains dalam Pembelajaran Keagamaan Islam. Edukasia: Jurnal Penelitian Pendidikan Islam, 14(2), 267296. 